\title{
POTENSI RUMPUT LAUT GRACILARIA SP SEBAGAI BAHAN ALTERNATIF DYE SENSITIZED SOLAR CELL (DSSC)
}

\author{
Aminatus Sa'diyah ${ }^{1 *}$, E. Alfianto ${ }^{2}$, Mohamad Nurul Huda', Dycka Anugerah SP1 \\ ${ }^{1}$ Teknik Permesinan Kapal,Politeknik Perkapalan Negeri Surabaya \\ email: am.sadiyah@ppns.ac.id \\ ${ }^{2}$ Sistem Komputer, Institut Teknologi Adhi Tama Surabaya
}

diterima tanggal : 22 Februari 2018 disetujui tanggal : 10 Mei 2018

\begin{abstract}
Abstrak
Rumput laut Gracilaria sp adalah salah satu komoditas di daerah perairan bagian selatan Porong, Sidoarjo. Telah dilakukan studi untuk mengetahui potensi rumput laut gracilaria sp sebagai material alternatif pelapis DSSC, dengan memanfaatkan fikoeritrin atau pigmen berwarna merah yang terkandung dalam tumbuhan tersebut. Nilai penyerapan cahaya diidentifikasi sebagai parameter untuk menentukan potensial dari fikoeritrin menggunakan metode regresi. Hasil yang diperoleh menunjukkan bahwa fikoeritrin yang terkandung dalam Gracilaria sp memiliki potensial penyerapan cahaya antara 489-545 nm yang nilainya mendekati panjang gelombang sinar matahari dengan rentang antara 300-800 nm. Dengan perolehan rentang tersebut disimpulkan bahwa Gracilaria sp dapat digunakan sebagai material alternatif DSSC.
\end{abstract}

Kata Kunci : Gracilaria, sp. Fikoeritrin, Regresi, Absorpsi Cahaya, DSSC

\begin{abstract}
Seaweed Gracillaria Sp. is one of the commodities Southern waters Porong Sidoarjo. This study was conducted to determine the potential of Seaweed Gracillaria Sp. as an alternative material of DSSC coating by utilizing phycoerithrin or red pigment contained in Algae plants. Light absorption value has identified as parameter to determine the potential of phycoerythrin using regression methods. The results of the study is that the phycoerythrin found in Gracillaria, Sp. has a potential light absorption in range 489-545 $\mathrm{nm}$ approximately in accordance with sun wavelength 300-800 $\mathrm{nm}$. As of it, phycoerythrin in Glacillaria Sp can be used for DSSC alternative material.
\end{abstract}

Keywords : Gracillaria, Sp., Phycoerythrin, Regression, Light Absorption, DSSC

\section{PENDAHULUAN}

Sel surya merupakan suatu perangkat yang dapat mengubah energi matahari menjadi energi listrik. Indonesia berpotensi untuk pengembangan teknologi sel surya sebagai salah satu sumber energi alternatif karena posisinya terletak pada garis khatulistiwa yang memungkinkan sinar matahari dapat diterima secara optimal [1]. Sel surya telah banyak dikembangkan mulai dari sel surya berbahan silikon tunggal, silikon polikristal, dan Dye Sensitized Solar Cell (DSSC). DSSC pertama kali ditemukan oleh Michael Gratzel dan Brian O’Regan pada tahun 1991 dan dikenal sebagai Gratzel Cells [2].
DSSC merupakan sel surya yang memanfaatkan warna alami. DSSC ini terdiri dari sepasang kaca berlapis dengan bahan TCO (Transparent Conducting Oxide) yang saling mengapit larutan elektrolit. Elektrolit berfungsi sebagai katalis untuk mempercepat reaksi redoks pada I/I3 (iodide/Triiodide). Kaca berlapis tersebut berfungsi sebagai elektroda yang dideposisikan oleh Titanuim dioxside $\left(\mathrm{TiO}_{2}\right)$ dengan transport elektron. Elektroda ini terdiri dari lapisan pigmen pewarna (antosianin) yang berfungsi sebagai donor elektron sedangkan elektroda lawan yang terlapisi oleh karbon [3]. 


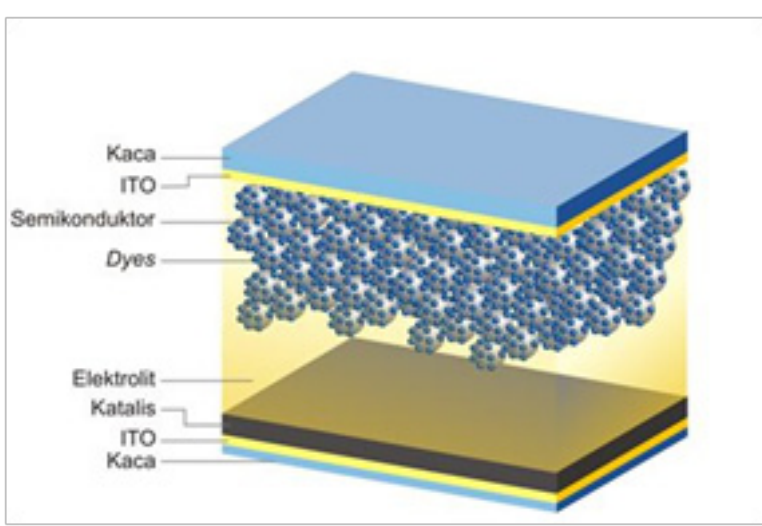

Gambar 1. DSSC (Dye Sensitized Solar Cell)

Bahan alami yang sering dimanfaatkan untuk fabrikasi DSSC adalah makroalga. Makroalga merupakan tumbuhan laut yang hidup daerah perairan dangkal. Salah satu jenis makroalga yang memiliki pigmen warna (Antosianin) adalah Gracilaria sp. Pigmen warna yang terdapat pada Gracilaria $s p$ adalah fikoeritrin atau pigmen warna merah yang dapat dimanfaatkan sebagai bahan alami pembuatan DSSC [4].

Fikoeritrin merupakan sebuah protein globular dan larutannya merupakan larutan multikomponen. Fikoeritrin mempunyai kestabilan yang tinggi dibandingkan dengan pigmen yang lain, dengan rentang $\mathrm{pH}$ antara 5,4-6,8 [5] dalam study yang lain disebutkan R-PE dapat stabil pada $\mathrm{pH}$ antara 3,5 sampai 9,5 [6]. Fikoeritrin telah ditemukan di beberapa jenis rumput laut merah seperti Gracillaria sp., Eucheuma sp., Porphyra yezoensis.

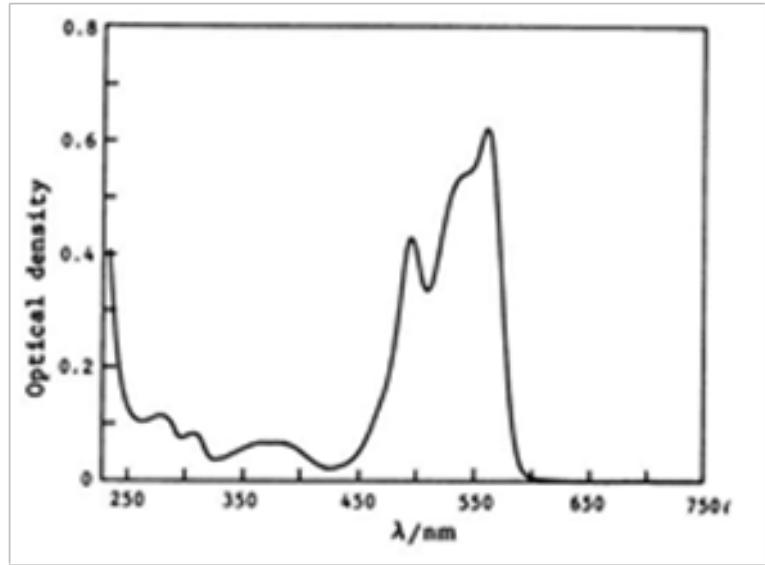

Gambar 2. Tipe serapan spektrum fikoeritrin pada $\mathrm{pH}$ 6,8. [5]
Fikoeritrin merupakan protein yang bekerja sebagai pigmen pelengkap pada algae merah dan alga biru-hijau seperti halnya fikobilin, berfungsi dalam sel alga untuk membantu klorofil-a dalam menyerap cahaya pada proses fotosintesis. Cahaya yang diserap oleh fikoeritrin secara efisiensi dipindahkan ke fikosianin, kemudian ke allofikosianin, diteruskan ke allofikosianin B dan terakhir ke klorofil [7].

Berdasarkan serapan spektranya fikoertitrin dibagi menjadi : B-fikoeritrin (B-PE), R-fikoeritrin (R-PE) dan C-fikoeritrin (C-PE), R-PE jenis fikobiliproteoin yang mendominasi algae merah [8]. Pigmen tersebut merupakan jenis pigmen yang larut air dan protein stabil. R-PE bisa digunakan dalam produksi makanan dan kosmetik, dan berperan penting dalam beberapa teknik biokimia yang berkaitan dengan sifat fluoresensinya [9]. R-PE biasanya dapat digunakan untuk pelabelan dalam immunologi, sel biologi dan flow cytometry [10], selain itu dapat digunakan sebagai bahan celup alami makanan dan sebagai penanda dalam gel elektroforesis dan isoelectrofocusing [11].

Salah satu pigmen dominan pada rumput laut merah adalah fikobilin yang terdiri dari fikoeritrin, fikosianin, dan allofikosianin [12]. Fikobilin merupakan protein, mempunyai cincin tetrapirol dan termasuk dalam gugus kromofor. Semua kromofor fikobilin mengikat sistein spesifik pada rantai polipetida oleh ikatan-ikatan tioeter [13].

Tabel 1. Klasifikasi biliprotein berdasarkan absorbansi panjang gelombang.[14]

\begin{tabular}{|c|c|c|c|c|c|c|}
\hline Biliprote in & Distribusi & $\begin{array}{l}\text { Absorbansi } \\
\text { maksimum } \\
(\mathrm{nm})\end{array}$ & $\begin{array}{c}\text { Emisi } \\
\text { fluoresensi } \\
\text { maksimum } \\
(n m)\end{array}$ & $\begin{array}{l}\text { Struktur } \\
\text { subunit }\end{array}$ & $\begin{array}{c}\text { Kancunga } \\
\text { kromofor } \\
\text { pada } \\
\text { promoter } \\
\text { (aß) }\end{array}$ & \\
\hline Allofikosianin B & C. A & $671>618$ & 675 & $(\alpha \beta)^{3}$ & $2 \mathrm{PCB}$ & \\
\hline Allofikosianin & C. A & 650 & 660 & $(\alpha \beta) 3$ & $2 \mathrm{PCB}$ & \\
\hline C-fikosianin & C. A & 620 & 640 & $\begin{array}{l}(\alpha \beta) 3 ; \\
(\alpha \beta) 6\end{array}$ & $3 \mathrm{PCB}$ & \\
\hline R-fikosianin & A & $617>555$ & 636 & $\begin{array}{l}(\alpha \beta) 3 ; \\
(\alpha \beta) 6\end{array}$ & $\begin{array}{l}2 \mathrm{PCB} ; \\
\mathrm{PCB}\end{array}$ & 1 \\
\hline Fikoerithrocianin & c & $570>595$ & 625 & $\begin{array}{l}(\alpha \beta) 3 ; \\
(\alpha \beta) 6\end{array}$ & $\begin{array}{l}2 \text { PCB; } \\
\text { PXB }\end{array}$ & 1 \\
\hline C-fikoeritrin & C & 560 & 577 & $\begin{array}{l}(\alpha \beta) 3 ; \\
(\alpha \beta) 6\end{array}$ & 5-6 PEB & \\
\hline b-fikoeritrin & A & $545>563$ & 570 & $(\alpha \beta) n$ & 6 PEB & \\
\hline B-fikoeritrin & A & $545>563>498$ & 575 & $(a \beta) 6 y$ & 6 PEB & \\
\hline R-fikoeritrin & C. A & $565>540>498$ & 578 & (aß) $6 \mathrm{y}$ & . & \\
\hline
\end{tabular}




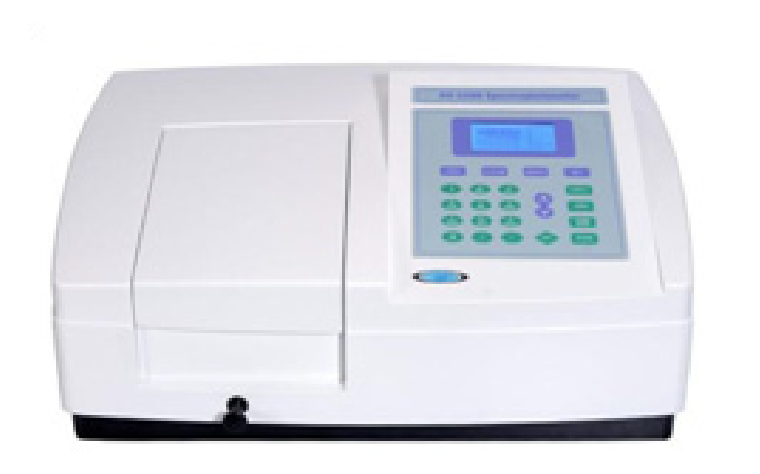

Gambar 3. Spektofotometer.

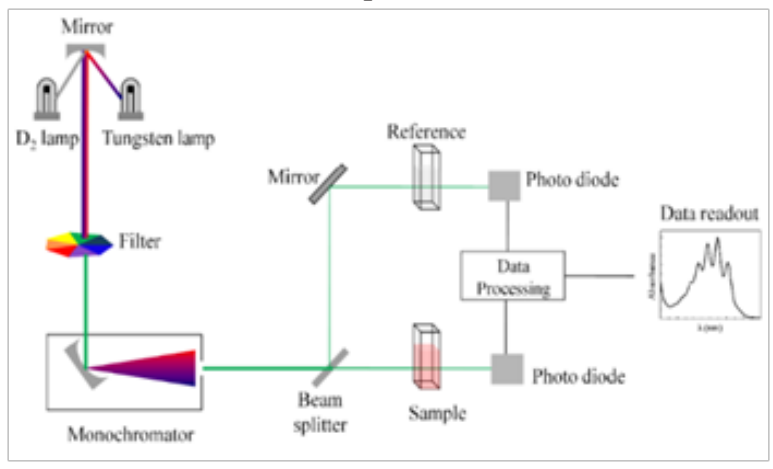

Gambar 4. Skema kerja Spektofotometer UV-Vis. [20]

Spektrofotometer UV-VIS Spektroskopi suatu perangkat yang menginteraksikan cahaya dengan atom dan molekul. Radiasi cahaya atau elektromagnet dapat dianggap menyerupai gelombang. Dasar spektroskopi UV -Vis adalah serapan cahaya.

Secara sederhana instrument spektrofotometer terdiri dari : sumber cahaya, monokromoator, sel sampel, detector dan read out (pembaca). Spektrofotometri visible disebut juga spektrofotometri sinar tampak[20].

Pada Gambar 4 merupakan rangkaian alat UV-Vis spektofotometer. Seberkas cahaya dari sumber cahaya ultra violet (UV) dan cahaya tampak (visible) dipisahkan menjadi komponen panjang gelombang dengan kisi difraksi. Setiap monokromatik dibagi menjadi dua berkas intensitas yang sama dengan perangkat half mirror. Satu berkas sinar melewat kuvet yang berisi larutan sampel. Sinar lain, referensi (standar) melewati sebuah kuvet identik yang hanya berisi pelarut. Instensitas dari berkas cahaya tersebut kemudian diukur dengan detektor elektronik dan dibandingkan. Intensitas berkas acuan, absobsi cahaya sedikit atau tidak ada, disebut sebagai I0. Intensitas berkas yang melewati larutan sample disebut I. Semua komponen panjang gelombang yang akan di inginkan akan secara otomatis dipindai oleh spektrofotometer [20].

Bila cahaya jatuh pada senyawa, maka sebagian dari cahaya diserap oleh molekulmolekul sesuai dengan struktur dari molekul senyawa tersebut. Serapan cahaya oleh molekul dalam daerah spektrum UV-Vis tergantung pada struktur elektronik dari molekul. Spektra UVVis dari senyawa-senyawa organik berkaitan erat dengan transisi-transisi diantara tingkatantingkatan tenaga elektronik. Spektrofotometri merupakan salah satu metode dalam kimia analisis yang digunakan untuk menentukan komposisi suatu sampel baik secara kuantitatif dan kualitatif yang didasarkan pada interaksi antara materi dengan cahaya [15].

DSSC (Dye Sensitized Solar Cell) yang memanfaatkan pigmen fikoeritrin pada alga untuk menghasilkan listrik sehingga masyarakat dalam produksi dengan menggunakan alat-alat elektrik yang sumbernya dari PLN bisa diganti dengan DSSC (Dye Sensitized Solar Cell) yang biayanya relatif lebih murah. Tujuan dari studi ini adalah untuk mengetahui kandungan fikoeritrin, karoten, xantofil yang terdapat pada Alga merah jenis Gracilaria sp. Hasil yang didapatkan dapat digunakan sebagai acuan untuk aproksimasi potensi Rumput laut Gracilaria sp jika digunakan sebagai bahan alternatif DSSC dengan memanfaatkan pigmen merah yang terkandung didalamnya..

\section{METODE PENELITIAN}

Studi dilakukan dengan mengambil sampel di Dusun Tanjung Sari Desa Kupang Kecamatan Jabon Sidoarjo dimana terdapat banyak tambak rumput laut. Rumput laut yang ditanam berjenis Gracilaria, sp yang merupakan salah satu Alga Merah.

Sampel tersebut digunakan untuk mengetahui kadar pigmen warna yang terdapat pada rumput laut Gracilaria $s p$. Dye alami yang dihasilkan dari alga merah rumput laut Gracilaria sp kemudian di karakterisasi dengan Spektofotometer UV-Vis untuk mengukur panjang gelombang yang diserap dan menghitung energi 
gap dye nya. Selanjutnya dilakukan analisis data regresi berdasarkan studi literatur mengenai kadar pigmen warna merah fikoeritrin yang terdapat pada Alga merah jenis Gracilaria sp untuk mengetahui hubungan emisi fluoresensi terhadap kemampuan absorbsi cahaya saat fotosintesis.

\section{HASIL DAN PEMBAHASAN}

Berdasarkan pengambilan sampel dan studi literature didapatkan hasil berupa hubungan antara fluoresensi dengan kemampuan absorbs panjang gelombang oleh billirubin yang dimiliki alga.

Alga memiliki karakteristik yang bisa diklasifikasikan menjadi 6 kelompok berdasarkan kemampuannya menyerap cahaya [18]. Kemampuan penyerapan cahaya dapat ditentukan dari tipe klorofil dan nilai absorbs terhadap fluoresensi maksimum berdasarkan pigmen warna [16].

Studi ini merupakan kajian awal untuk mengetahui potensi rumput laut Gracilaria $s p$ sebagai bahan alternatif DSSC berdasarkan kandungan fikoeritrin atau pigmen warna merah. Sehingga berdasarkan tabel 1 dapat diketahui bahwa alga merah (Gracilaria $s p$ ) memiliki kandungan karoten 0,947\%, xantofil 0,727\%, klorofil a 74,920 \%, fikoeritrin 8\%.

Tabel 2. Kadar pigmen dalam Alga [17]

\begin{tabular}{|l|l|l|l|l|}
\hline No & Filum Alga & Klorofil & Pigmen & $\begin{array}{l}\text { Billiprotein } \\
\text { fluoresensi (nm) }\end{array}$ \\
\hline 1 & Chlorophyta & a , b & $\begin{array}{l}\text { Karoten, } \\
\text { Xantofil }\end{array}$ & $380-490$ \\
\hline 2 & Phaeophyta & a, c & $\begin{array}{l}\text { Karoten, } \\
\text { Xantofil }\end{array}$ & 535 \\
\hline 3 & Rhodophyta & a, d & $\begin{array}{l}\text { Karoten, } \\
\text { Xantofil } \\
\text {,Fikoeritrin }\end{array}$ & $498-545$ \\
\hline 4 & Chrysoophyta & a , c & $\begin{array}{l}\text { Karoten, } \\
\text { Xantofil }\end{array}$ & 585,615 \\
\hline 5 & Phyrrophyta & a , c & $\begin{array}{l}\text { Karoten, } \\
\text { Xantofil }\end{array}$ & 544,563 \\
\hline 6 & Euglenophyta & a, b & $\begin{array}{l}\text { Karoten, } \\
\text { Xantofil }\end{array}$ & 620 \\
\hline
\end{tabular}




\section{KESIMPULAN}

Studi awal ini menghasilkan suatu kesimpulan yaitu DSSC (Dye Sensitized Solar Cell) dapat dimanfaatkan dengan mengkombinasikan bahan anorganik $\mathrm{TiO} 2$ dengan bahan organik alga merah yaitu Gracilaria sp. Pigmen warna yang dimanfaatkan untuk menyerap intensitas cahaya adalah fikoeritrin dengan kemampuan absorbsi pada cahaya dengan rentang panjang gelombang sebesar 498-545 $\mathrm{nm}$.

\section{DAFTAR PUSTAKA}

[1] Ardianto Rino . "Uji Kerja Dye Sensitized Solar Cell (DSSC) Menggunakan Lapisan Capacitive Touchscreen Sebagai Substrat dan Ekstrak Klorofil Nannochloropsis Sp. Sebagai Dye Sensitizer dengan Variasi Ketebalan Pasta $\mathrm{TiO}_{2}$,. Jurnal Keteknikan Pertanian dan Biosistem Vo. 3 no. 3 (2015) hal. 325-337

[2] B. O'Regan and M. Grätzel, "A low-cost, high-efficiency solar cell based on dyesensitized colloidal TiO2 films" Natural 353 (1991) pp. $737-740$.

[3] Choirul M. "Pembuatan Prototype Dye Sensitized Solar Cell (DSSC) Dengan Memanfaatkan Ekstrak Antosianin Strawberry". Prosiding Seminar Nasional dan Pendidikan Sains VII (2013), Vol. 4 No. I. ISSN : 2087-0922

[4] Firmanda, E. 2014. "Pigmen Fikoeritrin dari Mikroalga Porphydium cruentum Sebagai Fotosensitizer pada Sel Surya Tersensitisasi Dye”. IPB. Bogor

[5] Mizuno, T. 1979. "Illustration of the freshwater plankton of Japan”. Hoikusha Publishing Co.Ltd. Japan : 313 p.

[6] Kawsar, A. "Protein R-phycoerythrin From Marine Red Alga Amphiroa anceps: Extraction, purification and characterization”. Phytologia Balcanica 17 (3) : 347-354, Sofia, 2011.

[7] Chakdar H. "Potential application of blue green Algae". Journal of Scientific \& Industrial Research (2012). Vol. 71. Pp. 1320 .
[8] Marsac NT. "Phycobiliproteins and phycobilisomes : the early observations". Photosyntesis Research 76 : 2003. Netherlands : Kluwer Academic Publisher.

[9] Albertsson, PA. 2003. The contribution of photosynthetic pigments to the development of biochemical separation methods : 19001980. -Photosynth. Res, 76 (1-3): 217-225

[10] Wilson, GD. "Probing the Cell Cycle with Flow Cyometry". J. Biomedical Science and Engineering, 2014. 7. 698-711. SciRes. Scientific Research.

[11] Agnolo, D. “Isolation and Characterisation of a foaming fraction from hot water extract of roasted coffee”. Colloq. Sci. Int. Café $18^{\text {th }} .1999 .95-105$

[12] Pagulendren, S. "Extraction of R-Phycoerythrin from Kappaphycus alvarezii (Doty) Doty ex Silva and analyses of its physico-chemical properties. J. Acad. Indus. Res. Vol. 1 (7) 2012. P. 407. ISSN : 2278-5213

[13] Niu, J-F. Wang, G-C and Tseng, C-K. "Methods for Large Scale Isolation and Purification of R-Phycoerytrin Red Alga Polysiphonia urceolata Grev. Protein Expression and Purification, 49, No. 1, 23 (2006)

[14] Gary J, Wedemayer, Daniel G., David E, Wemmer, and Alexander D Glazer. Phycobilins of Cryptophycean Algae. The Journal of Biological Chemistry. Vol. 267. No. 11. pp. 7315-7331. 1992. The American Society for Biochemistry and Molecular Biology, Inc.

[15] Khopkar, SM. 2006. Basic Concepts of Analytical Chemistry. $3^{\text {rd }}$ edition. ISBN : 978-81-224-2092-0. New Age International Publisher..

[16] Jin-Ching Lee, Ming-Feng Hou, Hung Wen Huang, Fang-Rong Chang, Chi-Chen Yeh, Jen-Yang Tang, Hsueh-Wei Chang. Marine Algal natural products with anti-oxidative, anti-inflammatory, and anti-cancer properties. Cancer Cell International 2013, 13-55.

[17] Edward W. Wilde, Carl B. Fliermans. 
Fluorescence Microscopy for Algal studies. Transaction of the American Microscopical Society Vol. 98, No. 1 (Jan 1979), pp. 96102

[18] John T. O. Klirk. 2010. Light and Photosynthesis in Aquatic Ecosystems. Cambridge University Press. p.293-300

[19] Samsonoff WA, MacColl R. Biliproteins and phycobilisomes from cyanobacteria and red algae at the extremes of habitat. Springer. Archives of Microbiology. 2001, Vol. 176, Issue 6, pp 400-405. 